\title{
The European Statements of Hospital Pharmacy: the patient and healthcare perspective
}

\author{
Richard Price
}

\section{Correspondence to} Richard Price, Department of Policy and Advocacy, European Association of Hospital Pharmacy, 3 Rue Abbe Cuypers, Brussels 1040, Belgium; richard.price@eahp.eu

Accepted 8 August 2014
The hospital environment can be a frightening experience for patients, who may find themselves in a vulnerable position, ill, worried or in pain, but they can now count on hospital pharmacists to support them. During their recent Brussels Summit, EAHP worked together with key stakeholders to produce a ground breaking set of Statements that will ensure patients get the best possible care from their hospital pharmacists. This could be life-saving. (Hildrun Sundseth, President of the European Institute of Women's Health)

'No decision about me, without me' is an effective current expression used to highlight the need for greater patient involvement in the decisions that will ultimately impact them in the fullest sense of the word. It's a call that EAHP recognises and appreciates, and with this in mind, from the moment the concept of the European Summit on Hospital Pharmacy first emerged, the Steering Committee knew that it wanted the decisions about the future of hospital pharmacy in Europe to be of a shared nature. A definitive set of statements on the future of hospital pharmacy should be made not only by hospital pharmacists, but also in conjunction with patients, and indeed the other healthcare professionals hospital pharmacists work alongside in the hospital environment.

So from the summer of 2013 the recruitment of European patient and healthcare professional organisations began in earnest. This involved letters of invitation, in person meetings, emails and telephone calls until, by the time the first round of Delphi consultation opened in Autumn 2013, a total of 34 organisations had confirmed their interest in helping to shape future European Statements of Hospital Pharmacy (table 1).

The conduct and results of the Delphi consultation are described in more detail by Jonathan Underhill and Neal Maskrey (see page 264).

The organisations listed in table 2 were then able to send individual representation to the Summit event in May 2014, to participate in the final discussions on Statement wording, as well as the conclusive voting on the Statements (though it should be noted that some organisations were unable to be represented on the second day of the Summit, at which voting on the Statements took place).

The participation of patient and healthcare professionals in the Statement voting is described in the article by Dr Roberto Frontini.

At the end of the project, the Summit Steering Group is of confirmed belief that the direct involvement of patients, and the viewpoints gathered of other healthcare professionals, yielded new insights and brought additional value to the final outcome of the Summit: the 44 European Statements of Hospital Pharmacy.
But following the Summit, what are the views of the patient and healthcare professional organisations that took part?

The EAHP secretariat conducted telephone and email surveys with a number of the participant organisations to obtain their feedback (both positive, and constructively critical) as to how the Statement development process had operated from their perspective.

\section{REFLECTIONS ON THE STATEMENT DEVELOPMENT PROCESS}

All organisations contacted reported favourably on EAHP's desire to consult with them on forming the statements, with a representative from the European Crohn's and Colitis Organisation remarking that it was the first time her organisation had ever been approached and engaged by the pharmacy profession so directly.

However, one area of feedback raised by a number of organisations, was feeling a sense of unfamiliarity with online Delphi consultation methods. Many reported that the Delphi consultation on the draft statements was the first and only time they have been asked to contribute opinion in this way. There was also a concern that the time required to participate and familiarise with the consultation method may have been a barrier to participation for many. This might especially be the case in view of the typically large number of requests for opinion such organisations receive, set against often very resource constrained environments. Individual one-to-one meetings with EAHP at which the Delphi process was explained in person were therefore appreciated and felt to be useful. The value of the Delphi method in providing a comprehensive, transparent and rigorous approach to consultation was recognised however. A representative from the European AIDS Treatment Group commented: "methodologically, the approach was correct...on the level of transparency I was really pleased and satisfied". The challenge for any future endeavours of this nature may therefore lie less in identifying a better consultation method, as making participation for the unfamiliar easier and more straightforward.

More than one patient organisation commented that it may have been beneficial to have involved stakeholders external to hospital pharmacy even earlier in the process, for example in the first review of the Basel Statements, and in the design of the consultation and Summit process.

On the Summit event itself, a representative from the European Multiple Sclerosis Platform remarked: "I found the process of participation in the Summit very impressive. I especially thought that the way the working groups were set up worked 
Table 1 European patient and healthcare professional organisations that registered to participate in the online Delphi consultation on European Statements of Hospital Pharmacy, autumn 2013

\begin{tabular}{|c|c|}
\hline Patient organisations & $\begin{array}{l}\text { Healthcare professional } \\
\text { associations }\end{array}$ \\
\hline The European Patients Forum & $\begin{array}{l}\text { The Standing Committee of } \\
\text { European Doctors }\end{array}$ \\
\hline AGE Platform Europe & $\begin{array}{l}\text { The European Specialist } \\
\text { Nursing Organisations }\end{array}$ \\
\hline The European Aids Treatment Group & $\begin{array}{l}\text { The European Association of } \\
\text { Senior Physicians }\end{array}$ \\
\hline $\begin{array}{l}\text { The European Federation of Allergy and } \\
\text { Airways Diseases Patients' Associations }\end{array}$ & $\begin{array}{l}\text { The European Oncology } \\
\text { Nursing Society }\end{array}$ \\
\hline $\begin{array}{l}\text { The European Federation of Neurological } \\
\text { Associations }\end{array}$ & $\begin{array}{l}\text { The Foundation of European } \\
\text { Nurses in Diabetes }\end{array}$ \\
\hline Rare Diseases Europe & $\begin{array}{l}\text { The European Psychiatric } \\
\text { Association }\end{array}$ \\
\hline The European Public Health Alliance & $\begin{array}{l}\text { The European Federation of } \\
\text { Internal Medicine }\end{array}$ \\
\hline The International Diabetes Federation (Europe) & $\begin{array}{l}\text { The European Federation of } \\
\text { Neurological Societies }\end{array}$ \\
\hline Mental Health Europe & $\begin{array}{l}\text { The Council of International } \\
\text { Neonatal Nurses }\end{array}$ \\
\hline The Association of European Cancer Leagues & $\begin{array}{l}\text { The European Cancer } \\
\text { Organisation }\end{array}$ \\
\hline $\begin{array}{l}\text { The European Federation of Crohn's and } \\
\text { Ulcerative Colitis Associations }\end{array}$ & $\begin{array}{l}\text { The European Society for } \\
\text { Paediatric Oncology }\end{array}$ \\
\hline The European Genetic Alliances Network & $\begin{array}{l}\text { The European Union of Medica } \\
\text { Specialists }\end{array}$ \\
\hline $\begin{array}{l}\text { The European Heart and Lung Transplant } \\
\text { Federation }\end{array}$ & $\begin{array}{l}\text { The European Haematology } \\
\text { Association }\end{array}$ \\
\hline \multicolumn{2}{|l|}{ The European Institute of Women's Health } \\
\hline \multicolumn{2}{|l|}{ The European Kidney Patients Federation } \\
\hline \multicolumn{2}{|l|}{ The European Men's Health Forum } \\
\hline \multicolumn{2}{|l|}{ The European Multiple Sclerosis Platform } \\
\hline \multicolumn{2}{|l|}{ The European Cancer Patient Coalition } \\
\hline \multicolumn{2}{|l|}{ The European Heart Network } \\
\hline \multicolumn{2}{|l|}{ The European Haemophilia Consortium } \\
\hline The European Parkinson's Disease Association & \\
\hline
\end{tabular}

really well. There was much discussion and it allowed several perspectives to be put forward".

A Summit participant on behalf of the European AIDS Treatment Group remarked that the breaks between World Café sessions were valuable as well, allowing useful dialogue and sharing of perspective between participants.

A European Heart Network participant believed the Summit achieved its mission in terms of gaining patient input, adding: "it is one of the few events where I have seen so much patient involvement-it was a very participative event". This was echoed by a representative of the European Federation of Neurological Associations, who remarked: "I was really impressed by the whole process... I appreciated that all participants could contribute to the discussions in an equal way...all participants were positive. Everyone was eager to get the statements right".

A participant from Rare Diseases Europe noted that the input of patients changed the outcome in a number of areas: "The statements directly related to the patients are reflecting the patients' views. You can see that for some of them all the 12 patients representatives gave the same vote (strongly agreed) and could push the overall voting from agreed to strongly agreed".
Table 2 European patient and healthcare professional organisations represented at the European Summit on Hospital Pharmacy

\begin{tabular}{|c|c|}
\hline Patient organisations & $\begin{array}{l}\text { Healthcare professional } \\
\text { associations }\end{array}$ \\
\hline The European Heart Network & $\begin{array}{l}\text { The European Association of } \\
\text { Senior Physicians }\end{array}$ \\
\hline The European Aids Treatment Group & $\begin{array}{l}\text { The European Haematology } \\
\text { Association }\end{array}$ \\
\hline The European Parkinson's Disease Association & $\begin{array}{l}\text { The Standing Committee of } \\
\text { European Doctors }\end{array}$ \\
\hline The International Diabetes Federation (Europe) & $\begin{array}{l}\text { The European Federation of } \\
\text { Neurological Societies }\end{array}$ \\
\hline The European Multiple Sclerosis Platform & $\begin{array}{l}\text { The European Society of } \\
\text { Paediatric Oncology }\end{array}$ \\
\hline The European Institute of Women's Health & $\begin{array}{l}\text { The Council of International } \\
\text { Neonatal Nurses }\end{array}$ \\
\hline $\begin{array}{l}\text { The European Federation of Allergy and } \\
\text { Airways Diseases Patients' Associations }\end{array}$ & $\begin{array}{l}\text { The European Specialist } \\
\text { Nursing Organisations }\end{array}$ \\
\hline The European Public Health Alliance & $\begin{array}{l}\text { The Foundation of European } \\
\text { Nurses in Diabetes }\end{array}$ \\
\hline Rare Diseases Europe & $\begin{array}{l}\text { The European Oncology } \\
\text { Nursing Society }\end{array}$ \\
\hline \multicolumn{2}{|l|}{ The European Cancer Patient Coalition } \\
\hline \multicolumn{2}{|l|}{ The European Haemophilia Consortium } \\
\hline European Patients Forum & \\
\hline
\end{tabular}

\section{UNDERSTANDING HOSPITAL PHARMACY}

Organisations considered that by participating in the Summit their understanding and appreciation of hospital pharmacy had been greatly assisted. Specific areas of hospital pharmacy practice covered in the statements that patient organisations reported to be illuminating included the hospital pharmacy's role in medicines production and general management of patient medication.

A representative of the European Parkinson's Disease Association mentioned that her improved consciousness of the services hospital pharmacies offer has heightened her awareness of the need for hospital pharmacists to take greater roles within the healthcare team providing care to the patient. She also expressed being 'really shocked' to learn of how much hospital pharmacy time was currently being devoted to sourcing medicines in shortage.

A participant on behalf of the European AIDS Treatment Group commented: "It was quite an eye-opener...it was really new and I enjoyed this. I thought my primary focus would be on the patient safety section but I was pleasantly surprised by how many other aspects of the statements were important to us, such as procurement and distribution".

A European Heart Network representative reflected after the Summit on the value that could be gained in improving public awareness and understanding of the role of the hospital pharmacist: "Very often, it may be the case that the patient does not fully understand the role of the health professional in the white coat they are speaking with". Such sentiments were shared by the representative of the European Crohn's and Colitis Organisation who remarked: "For patients, hospital pharmacy is something they really don't know. It is clear however that having a better understanding of hospital pharmacy's role is important".

A representative from Rare Diseases Europe said: "During the 12 years that Rosie and I went to the hospital, we never met a hospital pharmacist, only the Prof, doctors and the specialized 
nurses. I think it's important that when a patient starts a new treatment he can meet the specialist; the hospital pharmacist and discuss about practical aspects like interactions of drugs, side effects, appropriateness of medications etc. Hoping this will be improved with the new practices".

\section{OTHER REFLECTIONS}

Other points of constructive feedback, in relation to any organisation considering replication of the European Summit on Hospital Pharmacy, was a recommendation to provide explicit guidance material addressing the questions of "What is expected by participants" and "How to ensure full participation by your organisation". These points of feedback may relate again to the unprecedented nature of the Summit in terms of the more typical 'speaker-panellists-questions' stakeholder events held in the Brussels environment.

The European Parkinson's Disease Association was particularly pleased that its representations on the need for the perspective of carers to be recognised within the statements were so readily accepted, and appreciated the strong emphasis within the statements in relation to patient rights.

\section{PATIENT ENTHUSIASM VERSUS HEALTH PROFESSIONAL CAUTION?}

From my own perspective, it is an observation worth sharing, and supported by respective participation levels achieved, that the recruitment of participation in the Statement development process from outside the profession was notably easier with patient organisations than with other healthcare professional organisations. One might make numbers of suggestions for why this should be the case. My own speculation is that the patient interest represented within the Statements is more immediately self-evident than the interest provided to fellow healthcare professionals-even though this interest is undoubtedly present, and was recognised by healthcare professional organisations once having commenced participation.

In summary, the decision by the Summit Steering Group to design a process of Statement creation that involved patient organisations and healthcare professionals as equal partners, was known at the time to be both bold, and associated with risks. But the rewards of this risk are evident in the robustness of the statements, and the value added by the additional inputs received.

There is a Danish proverb that states: "He who is afraid of asking is ashamed of learning". Through the Summit's openness to asking those outside the profession what hospital pharmacy should achieve in the future, I believe EAHP's member countries showed no sense of shame in learning what might be said in response. As it happens, the responses received served to heighten and elevate both the content of the future vision for hospital pharmacy, and the platform of support on which it is founded.

Competing interests None.

Provenance and peer review Commissioned; internally peer reviewed. 